See discussions, stats, and author profiles for this publication at: https://www.researchgate.net/publication/320206002

Studies on Homalomeneae (Araceae) of Borneo XX: Homalomena lambirensis sp. nov. from Sarawak with well-recorded pollination biology

Article in Nordic Journal of Botany · October 2017

DOI: $10.1111 /$ njb.01589

CITATIONS

5

2 authors:

Wong Sin Yeng

Harvard University

202 PUBLICATIONS 1,207 CITATIONS

SEE PROFILE
READS

571

Ludwig-Maximilians-University of Munich

363 PUBLICATIONS 3,274 CITATIONS

SEE PROFILE

Some of the authors of this publication are also working on these related projects:

Euro-Mediterranean Araceae View project

The Fifth International Conference on Natural Resources in the Tropics (NRTrop5), 27th November 2017-1st December 2017 View project 


\title{
Studies on Homalomeneae (Araceae) of Borneo XX: Homalomena lambirensis sp. nov. from Sarawak with well-recorded pollination biology
}

\author{
Sin Yeng Wong and Peter C. Boyce \\ S. Y. Wong (sywong@unimas.my), Dept of Plant Science and Environmental Ecology, Faculty of Resource Science and Technology, Univ. Malaysia \\ Sarawak, Kota Samarahan, Sarawak, Malaysia. SYW also at: Harvard Univ. Herbaria, Cambridge, MA, USA. - P. C. Boyce (http://orcid. \\ org/0000-0002-5856-9561), Ludwig-Maximilians-Univ. München, Dept Biologie I, Systematische Botanik und Mykologie, München, Germany. \\ PCB also at: Inst. for Tropical Biology and Conservation, Univ. Malaysia Sabah, Kota Kinabalu, Sabah, Malaysia.
}

\begin{abstract}
Homalomena lambirensis S. Y. Wong \& P. C. Boyce is described and illustrated as a new species of the Homalomena Hanneae complex [Cyrtocladon clade] from Lambir Hills National Park, northeast Sarawak, Malaysian Borneo to where it is endemic. Comparison with the described Bornean species of the Hanneae complex is made and an identification key to species is provided. Homalomena lambirensis has previously been the subject of detailed pollination biology studies under the erroneous identity Homalomena propinqua Schott (=H. rostrata Griff.). Recognition of H. lambirensis takes to 10 the total of described species for the Hanneae complex.
\end{abstract}

Homalomena is taxonomically the most challenging genus of Araceae in tropical Asia, with numerous poorly-defined historical taxa typically based on inadequate herbarium specimens, including widespread and vegetatively highly variable species with predictably large synonymies, and a significant quantity of taxonomic novelties (Boyce and Wong 2008, 2015). Given this, it will come as no surprise that Homalomena species names are frequently misapplied in non-taxonomic publications, in particular in publications describing pollination studies. One compelling example, comprising three papers (Kato et al. 2000, Kumano and Yamaoka 2006, Kumano-Nomura and Yamaoka 2009) concerns a highly detailed study undertaken in Lambir Hills National Park, northeast Sarawak of a mesophytic plant determined by the researchers as Homalomena propinqua Schott, a synonym of the helophytic $H$. rostrata Griff. (Wong et al. 2011), but clearly not that species. As part of our ongoing research in Homalomena pollination (Tung et al. 2010, Hoe et al. 2011, 2016) we decided to identify the Lambir Homalomena species in order to better relate the pollination biology information.

Fieldwork at Lambir Hills National Park undertaken over Christmas and New Year 2014/2015 located significant populations of a medium-sized Homalomena with characteristically impressed primary veins giving the leaf blades a quilted appearance. Unfortunately, the visit coincided with protracted unseasonably dry weather such that despite extensive searching we failed to locate flowering plants. Young plants were, however, collected for cultivation and have now flowered and convincingly match the inflorescences depicted in Kumano and Yamaoka (2006). Furthermore, this is only species of Homalomena present at Lambir that vegetatively corresponds to the original (albeit incorrect) determination as Homalomena propinqua. The presence of extra floral nectaries on the leaf blades, together with resin-like droplets secreted from between staminate flowers during staminate anthesis, and a spathe limb turning from white at anthesis to medium pink during fruiting indicate placement in the Homalomena Hanneae complex (Ng et al. 2011, Wong et al. 2013), but it differs from all described species of the Hanneae complex by a combination of soon-marcescent petiolar sheath, cream pistillate flowers, and quilted leaf blades with the posterior lobes separated by a broadly parabolic sinus. Accordingly, we consider these plants to represent a taxonomic novelty, here described as Homalomena lambirensis.

\section{Homalomena lambirensis S. Y. Wong \& P. C. Boyce sp. nov. (Fig. 1)}

Previously referred to as: Homalomena propinqua sensu Kato et al. (2000), Kumano and Yamaoka (2006), KumanoNomura and Yamaoka (2009), non Homalomena propinqua Schott (1864, p. 280).

A species belonging to the Homalomena Hanneae complex as characterized by leaf blades with scattered extrafloral nectaries, resin-like droplets secreted from between staminate flowers during staminate anthesis, and a spathe limb turning from white (during anthesis) to medium pink or medium-red 

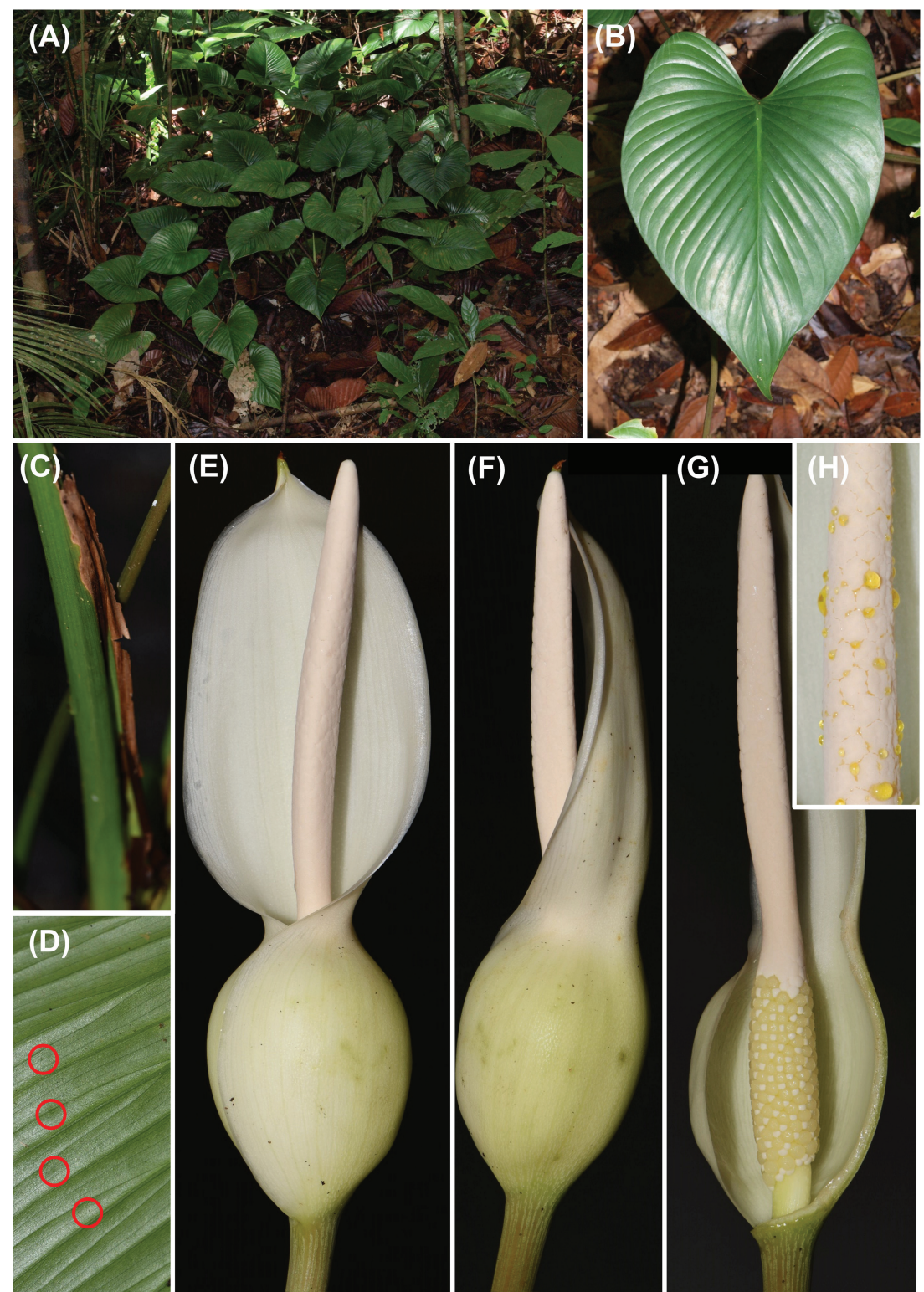

Figure 1. Homalomena lambirensis sp. nov. (A) plants in habitat, (B) leaf blade adaxial view, (C) detail of marcescent petiolar sheath wings, (D), leaf blade adaxial surface with extrafloral nectaries ringed in red, (E)-(F) inflorescence at pistillate anthesis, $(\mathrm{G})$, inflorescence at pistillate anthesis, nearside spathe artificially removed, $(\mathrm{H})$ detail of staminate flower zone with resin droplets.

during fruiting, most closely resembling $H$. sengkenyang P.C.Boyce, S.Y.Wong \& Fasihuddin and H. mutans P.C. Boyce \& S.Y. Wong by possessing a soon-marcescent petiolar sheath and sparse extra floral nectaries, but readily differentiated from either by overall larger stature, cream (not green $[H$. sengkenyang $]$ or brilliant pink $[$ H. mutans $]$ ) pistillate flowers, and additionally from $H$. sengkenyang by leaf blades with a broadly parabolic (not markedly narrow) sinus between the posterior lobes. Furthermore, Homalomena lambirensis differs from all other described species of the Hanneae complex by the combination of soon-marcescent petiolar sheath, cream pistillate flowers, and quilted leaf blades with posterior lobes separated by a broadly parabolic sinus.

Type: Malaysian Borneo, Sarawak, Miri, Beluru, Lambir Hills National Park, Inoue Trail, $04^{\circ} 12^{\prime} 09.4^{\prime \prime} \mathrm{N}, 114^{\circ} 01^{\prime} 51.4^{\prime \prime} \mathrm{E}$,
25 Dec 2014, Wong Sin Yeng and P. C. Boyce AR-5038 (holotype: SAR, isotypes: SAR (alcohol), SING).

\section{Etymology}

The epithet is derived from the name of the type locality with the addition of the Latin suffix -ensis, to indicate origin.

\section{Description}

Medium-sized somewhat robust, evergreen, glabrous herb to ca $1 \mathrm{~m}$ tall. Crushed tissues strongly aromatic of mango resin. Stem pleionanthic, initially erect, decumbent with age with ascending active tip, $2.5-3.5 \mathrm{~cm}$ thick, semi-glossy medium green; older parts brown and slightly corky; adventitious roots copious, conspicuous, often penetrating petiole bases and occasionally growing up inside of older sheathing 
petioles; internodes $1.5-2.5 \mathrm{~cm}$ long. Leaves up to ca 14; individual modules beginning with a conspicuous 2-keeled semi-persistent medium green prophyll; petiole $65-75 \mathrm{~cm}$ long $\times 8-13 \mathrm{~mm}$ wide, erect to spreading, pulvinate ca $2 / 3$ way along from base, $\mathrm{D}$-shaped in cross-section with angles rounded, distally shallowly canaliculate with the angles bluntly rounded, medium green with broken paler longitudinal striae; petiolar sheath $15-23 \mathrm{~cm}$ long, ca $1 / 3$ of petiole length, with wings up to $1 \mathrm{~cm}$ wide proximally, tapering distally, open, weakly decurrent at apex, their margins slightly incurved; wings initially medium green, soon marcescent along margin, eventually whole sheath marcescent; blade broadly ovato-sagittate or ovato-cordate, $35-45 \mathrm{~cm}$ long $\times 26-39 \mathrm{~cm}$ wide, thinly leathery; larger leaves quilted between impressed primary veins, blades with scattered inconspicuous minute punctate extrafloral nectaries) present on leaf blade, semi-glossy dark green adaxially, slightly paler abaxially, sagittate at base with sinus widely parabolic; posterior lobes subtriangular, obtuse at apex; anterior lobe broadly triangular, acute to short-cuspidate for ca $2 \mathrm{~cm}$; midrib raised abaxially, ca $7 \mathrm{~mm}$ wide at base, $4 \mathrm{~mm}$ wide at centre, adaxially impressed, ca $5.5 \mathrm{~mm}$ at base, ca $2.5 \mathrm{~mm}$ at centre; primary lateral veins ca 15 on each side, diverging at $30-90^{\circ}$ from midrib, adaxially impressed, abaxially sharply raised, curved towards apex when near margin; interprimary veins slightly impressed adaxially, slightly raised abaxially, alternating irregularly with primaries, posterior lobes each with 3-4 primary lateral veins; secondary venation abaxially raised, arising from mid-rib and primary and interprimary veins; tertiary venation invisible, all veins running into a slightly thickened intermarginal vein. Inflorescences usually up to 4, erect, smelling intensely of anethole at pistillate anthesis and again at staminate anthesis, but smell much reduced during inter-anthesis and post-staminate anthesis; first inflorescence subtended by a somewhat reduced foliage leaf; subsequent inflorescences in sympodium subtended by a 2-keeled medium green prophyll, ca $7 \mathrm{~cm}$ long $\times 1.5 \mathrm{~cm}$ wide; peduncle $16-18 \mathrm{~cm}$ long $\times 5.0-7.5 \mathrm{~mm}$ wide, glabrous, semi-glossy medium green with numerous pale yellowish broken longitudinal striae and shallow fissures. Spathe ca $15 \mathrm{~cm}$ long $\times$ ca $3.7 \mathrm{~cm}$ wide; lower spathe inflating and spathe limb loosening at anthesis, then inflating and then opening wide, white, dorsally with a pale green median band corresponding to mid-keel; lower spathe ultimately broadly ovoid-ellipsoid, ca $5.5 \mathrm{~cm}$ long $\times$ ca $2.7 \mathrm{~cm}$ wide at pistillate anthesis, its spathe strongly constricted with constriction coinciding with staminate flower zone constriction; spathe limb exceeding lower spathe, ca $9.5 \mathrm{~cm}$ long $X$ ca $3.7 \mathrm{~cm}$ wide at pistillate anthesis, ovato-triangular, with terminal mucro to ca $3 \mathrm{~mm}$, greenish. Spadix stipitate, $12-16 \mathrm{~cm}$, ca $1.4 \mathrm{~cm}$ rapidly extending at pistillate anthesis until exceeding spathe limb by ca $1 \mathrm{~cm}$; stipe ca $10 \mathrm{~mm}$ long $X$ ca $5 \mathrm{~mm}$ wide, compressed fusiform, inserted obliquely on peduncle, yellowish white; pistillate flower zone ca 3.5 $\mathrm{cm}$ long $\times 1.3 \mathrm{~cm}$ wide, ca $1 / 3$ length of spadix, slightly fusiform-cylindrical, yellowish; pistils $1.4-2.2 \mathrm{~mm}$ in diameter, ca $1.5 \mathrm{~mm}$ tall, globose-cylindrical, crowded, yellowish; interpistillar staminodes one per pistil, stipitate with a globose head $0.8-1.0 \mathrm{~mm}$ in diameter, not quite equalling pistils in height, waxy white; style barely differentiated; stigma globose-capitate, about as wide as ovary with the edges of adjacent stigmas touching, greenish white, wet at anthesis; suprapistillar interstice with ca two incomplete rows of rounded staminodes, ivory; staminate flower zone $9.0-10.5 \mathrm{~cm}$ long $\times$ ca $7.7 \mathrm{~mm}$ wide at staminate anthesis, ca $2 / 3$ length of spadix, weekly constricted ca $1 / 3$ way along from base coinciding with spathe constriction; amber droplets of resin secreted from between staminate flowers prior to onset of staminate anthesis; staminate flowers polygonal in plan view, $2.0-3.5 \mathrm{~mm}$ in diameter, each comprising $4(-6)$ truncate stamens each overtopped by large and flat connective tissue, ivory white; pollen in short strings white, forming a paste when mixed with resin. Infructescence $1-4$ together, declinate to pendent; spathe entirely persistent, rich pink; peduncle semi-glossy medium green with conspicuous striae; lower fruiting spathe $\mathrm{ca} 10 \mathrm{~cm}$ long $\times 2.1 \mathrm{~cm}$ wide; fruiting spathe limb ca $6.5 \mathrm{~cm}$ long $\times$ ca $1.1 \mathrm{~cm}$ wide; fruits not observed.

\section{Distribution and ecology}

Homalomena lambirensis is so far only known from Lambir Hills National Park, where it occurs in moderate populations in semi-shaded to somewhat open (although still forested) slightly sloping areas along the main trails on rather sandy soils derived from Miocene sediments under perhumid lowland to lower hill forest between 100-250 m a.s.l.

\section{Notes}

The misapplication of the name $H$. propinqua to the Lambir Hills plants is unsurprising given that only rather recently have attempts begun to clarify the taxonomy of Bornean Homalomena. The name Homalomena propinqua (Fig. 2) is based on a Pieter Korthals sterile collection from Mt Gintang (modern Gunung Bintang) on the Kalimantan Tengah/ Seletan border, Indonesian Borneo (Wong et al. 2011, p. 311) on to which Scott somewhat capriciously inserted an inflorescence description based on Motley's Labuan Island collection used to describe Homalomena sagittifolia Jungh. ex Schott. The type of Homalomena propinqua unequivocally falls within the variability of leaf blade shape exhibited by the widespread helophyte $H$. rostrata Griff.

The earlier name Homalomena sagittifolia Jungh. ex Schott (Fig. 3), is another element of Homalomena rostrata, based on a James Motley collection from Labuan island in the Bay of Brunei.

The pollination biology of Homalomena lambirensis was studied extensively by Kato et al. (2000), Kumano and Yamaoka (2006) and Kumano-Nomura and Yamaoka (2009). Two beetle species - Parastasia bimaculata Guerin (Scarabaeidae) and Chaloenus schawalleri (Chrysomelidae), the latter reported initially as Dercetina sp. by Kumano and Yamaoka (2006) - are attracted to open inflorescences by heat-production and floral odour (Parastasia) or floral odour alone (Chaloenus). Analyses of the floral odour revealed 18 compounds, the main ones being 2-butanol (the main compound), 1,2-dimethoxybenzene (veratrole), and $\alpha$-pinene. Artificially prepared combinations including 2-butanol or veratrole attracted both beetles, while veratrole alone attracted only $C$. schawalleri. The conclusion was that P. bimaculata was the most efficient pollinator. 


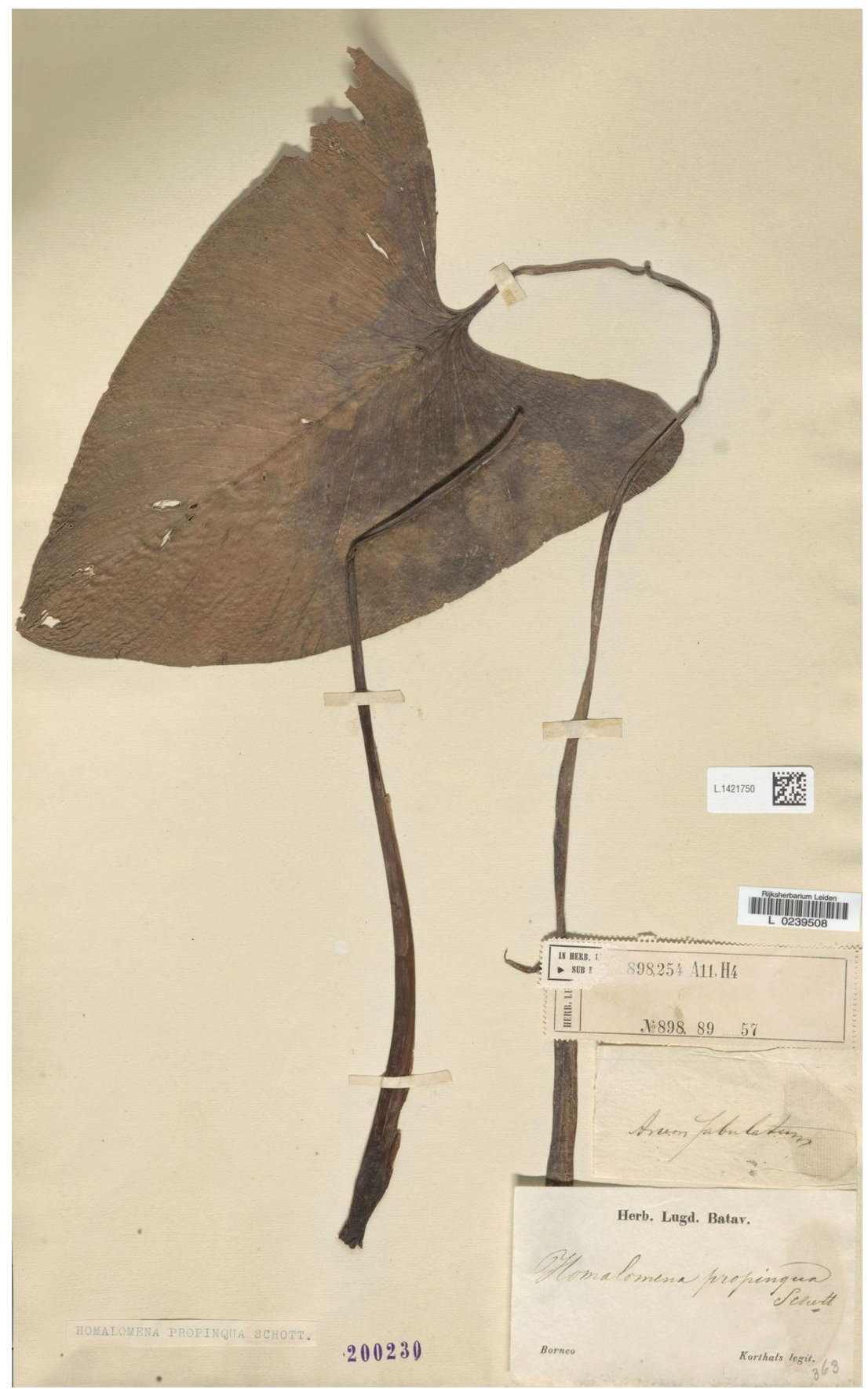

Figure 2. Homalomena propinqua Schott. P.W.Korthals s.n., Leiden holotype.

\section{Key to species of Homalomena Hanneae complex on Borneo}

1. Petioles and peduncles with conspicuous prominently raised glossy cherry-red unbroken ridges. Mulu (northeast Sarawak), southwest Brunei, shales H. striatieopetiolata

- Petioles and peduncles with inconspicuous pale broken longitudinal striae

2. Peduncle minutely puberulent (appearing velvety), deep maroon; leaf blades abaxially glaucous. Santubong (northwest Sarawak), hard Paleocene sandstones H. velutipedunculata

- Peduncle glabrous, green to reddish; leaf blades abaxially never glaucous ......................... 3

3. Pistillate flower zone abruptly wider than staminate flower zone; pistils pale orange. Batang Ai (Sarawak) to north part of Ulu Sungai Kapuas (Kalimantan Timur), Paleocene sandstones ............ H. hanneae - Pistillate flower zone imperceptibly merging with, or slightly narrower than, staminate flower zone; pistils not pale orange ............................ 4 


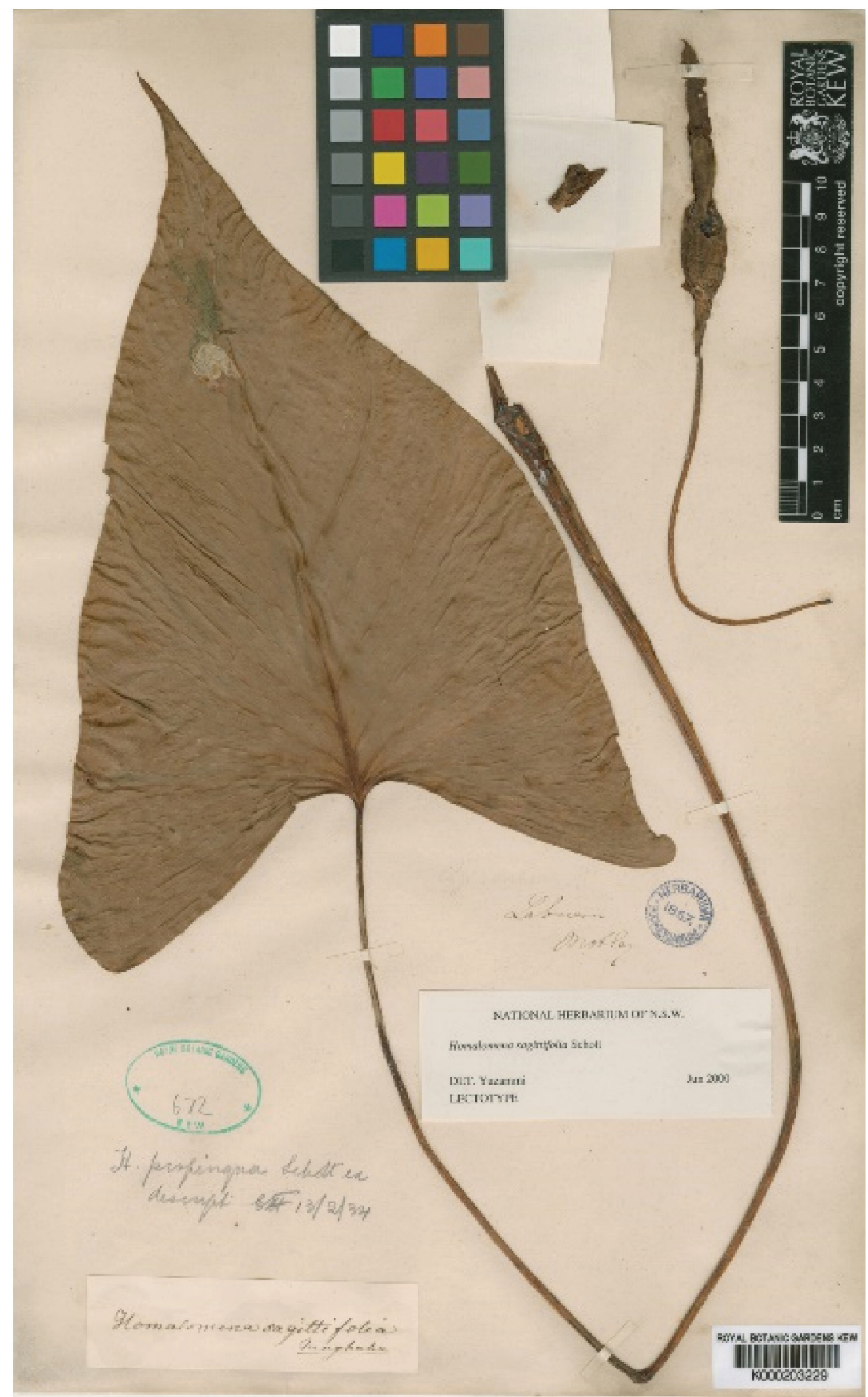

Figure 3. Homalomena sagittifolia Jungh. ex Schott - J.Motley s.n., Kew holotype.

4. Petiolar sheath margins soon marcescent

- Petiolar sheath margins long-persistent

........... 5

.......... 7

5. Sinus between leaf blade posterior lobes very narrow, lobe inner margins almost parallel; pistillate flowers green. Batang Ai (south central Sarawak) ......... H. sengkenyang - Sinus between leaf blade posterior lobes widely parabolic, lobe inner margins widely divergent, pistillate flowers not green

6. Pistillate flowers creamy white; stigma about as wide ovary; interstice staminodes reduced to two incomplete rows. Lambir Hills (northeast Sarawak), Miocene sandstones
- Pistillate flowers bright reddish pink; stigma about half as wide as ovary; interstice staminodes in about 5 rows. Environs of Kapit (central Sarawak), shales H.mutans

7. Leafblade glossy dark reddish green adaxially, dark purplered abaxially; inner margins of posterior lobes (i.e. facing across sinus) rounded, edges almost touching in robust specimens. Mulu (northeast Sarawak), riverine alluvial forest associated with karst limestone ............ H. ardua - Leaf blade glossy medium green adaxially, somewhat paler abaxially; inner margins of posterior lobes (i.e. facing across sinus) straight, edges divergent .. 8 
8. Leaf blade not or only very weakly quilted between primary lateral veins; petiole and peduncle dull purple red with conspicuous paler longitudinal ridges; spathe limb with red margin. Bintulu (north Sarawak), on alluvium in seasonally flooded forest ............ H. josefi - Leaf blade conspicuously quilted between primary lateral veins

9. Resin remaining in fissures between individual staminate flowers, not forming droplets; during fruiting lower part of persistent spathe ventrally much expanded with dorsal side almost flat. Siburan (southwest Sarawak), karst limestones ............................ gastrofructa - Resin forming droplets on staminate flower zone; during fruiting lower part of persistent spathe expanding equally ventrally and dorsally, eventually fusiform. Matang (west Sarawak), soft Paleogene sandstones H. debilicrista

Acknowledgements - The collaboration and support of the Sarawak Forestry Department and the Sarawak Biodiversity Centre are gratefully acknowledged.

Funding - This is an output of an ongoing research programme funded by the Ministry of Education Malaysia by the Niche Research Grant Scheme Vote no. NRGS/1089/2013-(03).

Permits - Fieldwork associated with this paper was most recently under Sarawak Forestry Dept Permission to Conduct Research on Biological Resources, permit no. NCCD.907.4.4 (JLD.13)-237 and Park Permit no. WL015/2016.

\section{References}

Boyce, P. C. and Wong, S. Y. 2008. Studies on Homalomeneae (Araceae) of Borneo I: four new species and speculation on informal species groups in Sarawak. - Gard. Bull. Singapore 60: $1-29$.
Boyce, P. C. and Wong, S. Y. 2015. Compendium genera Aracearum Malesianum. - Aroideana 38: 40-177.

Hoe, Y. C. et al. 2011. Studies on Homalomeneae (Araceae) of Borneo VII: Homalomena debilicrista a new species from Sarawak, Malaysian Borneo, with observations on its pollination. - Plant Div. Evol. 129: 77-87.

Hoe, Y. C. et al. 2016. Flowering mechanisms, pollination strategies and floral scent analyses of syntopically co-flowering Homalomena spp. (Araceae) on Borneo. - Plant Biol. 18: 563-576.

Kato, M. et al. 2000. Various population fluctuation patterns of light-attracted beetles in a tropical lowland dipterocarp forest in Sarawak. - Pop. Biol. 42: 97-104.

Kumano, Y. and Yamaoka, R. 2006. Synchronization between temporal variation in heat generation, floral scents and pollinator arrival in the beetle-pollinated tropical Araceae, Homalomena propinqua. - Plant Spec. Biol. 21: 173-183.

Kumano-Nomura, Y. and Yamaoka, R. 2009. Beetle visitations, and associations with quantitative variation of attractants in floral odors of Homalomena propinqua (Araceae). - J. Plant Res. 122: 183-192.

Ng, K. K. et al. 2011. Studies on Homalomeneae (Araceae) of Borneo VIII: delimitation of additional informal suprageneric taxa for Sundaic Homalomena. - Webbia 66: 21-28.

Schott, H. W. 1864. Araceae. - In: Miquel, F. A. G. (ed.), Mantissa Araliacearum, Eriicacearum, Cupuliferarum et Aracearum. Annales Musei Botanici lugduno-batavi 1: 278-286.

Tung, L. S. et al. 2010. Studies on Homalomeneae (Araceae) of Borneo VI: Homalomena giamensis, a new species from Sarawak, Malaysian Borneo, with notes on its pollination. - Aroideana 33: 201-211.

Wong, S. Y. et al. 2011. Studies on Homalomeneae (Araceae) of Borneo III: the helophytic Homalomena of Sunda. - Gard. Bull. Singapore 62: 313-325.

Wong, S. Y. et al. 2013. Phylogeny of Asian Homalomena (Araceae) based on the ITS region combined with morphological and chemical data. - Syst. Bot. 38: 589-599. 